\title{
To Formalize or Not to Formalize: Women Entrepreneurs' Sensemaking of Business Registration in the Context of Nepal
}

\author{
Shova Thapa Karki ${ }^{1} \mathbb{C} \cdot$ Mirela Xheneti $^{2} \cdot$ Adrian Madden $^{3}$
}

Received: 13 June 2019 / Accepted: 18 May 2020 / Published online: 22 May 2020

(c) The Author(s) 2020

\begin{abstract}
Despite the depiction of decisions to formalize informal firms as rational and ethical, many entrepreneurs in developing countries continue to operate informally regardless of its perceived illicit status. While existing research on why entrepreneurs choose informality emphasizes the economic costs and benefits of such decisions, this often overlooks the realities of the informal economy and the constraints which marginal populations-particularly women-face. In this paper, we use institutional theory and sensemaking to understand the experiences of women in the informal economy and what formalization means to them. We use a qualitative approach to collect data from 90 women entrepreneurs in three different cities in Nepal. In our findings we identify three groups of women with distinctive understandings of formalization-business sustainability, livelihood sufficiency and strategic alignment. Their interpretation of formalization reveals the complex, dynamic, and cyclical nature of formalization decisions. Decisions are also guided by the optimization of social and emotional logics, whereby formalization is conceived differently depending on different life stages, experiences within the informal economy and wider socio-cultural contexts. Our findings highlight the ethical implications of formalization where being a 'good citizen', rather than complying with formal rules and regulations, is about attuning to and fitting in with socially prescribed roles. Our research provides a nuanced view of formalization decisions, challenging idealized and ethical notions of formalization as a desired end state.
\end{abstract}

Keywords Formalization $\cdot$ Informal economy $\cdot$ Women entrepreneurship $\cdot$ Context $\cdot$ Sensemaking

\section{Introduction}

Shova Thapa Karki

s.thapa-karki@sussex.ac.uk

Mirela Xheneti

m.xheneti@sussex.ac.uk

Adrian Madden

a.madden@greenwich.ac.uk

1 School of Business, Management and Economics, University of Sussex, 209 Jubilee Building, Falmer, BrightonEast Sussex BN1 9SL, UK

2 School of Business, Management and Economics, University of Sussex, 218 Jubilee Building, Falmer, BrightonEast Sussex BN1 9SL, UK

3 Department of Human Resources and Organisational Behaviour, Business School, University of Greenwich, Old Royal Naval College, Park Row, Greenwich, London SE10 9LS, UK
The informal economy contributes between 40 and $60 \%$ of developing countries' GDPs (Vanek et al. 2014) and provides more than $60 \%$ of total employment in non-agricultural employment (ILO 2014). It comprises unregistered firms, those that do not pay taxes or offer formal/standard work contracts or social protections to their employees (Webb et al. 2009). The informal sphere is often depicted as a transitory or incubatory space for entrepreneurial activities. However, for many, especially women, it represents a space of vulnerability characterized by discontinuous careers linked to reproductive roles, poor education and ill-health (Ulrichs 2016). Policies to reduce vulnerability and poverty in developing country contexts have traditionally emphasized moving people out of the informal economy through business formalization as the path to economic development (Williams and Nadin 2014).

Formalization is commonly defined as the registration of informal firms with local, regional and/or national 
government agencies (Williams and Nadin 2010). It is thus presented normatively as the rational and ethical decision to make, by increasing the legitimacy of business activities and entrepreneurs through their engagement with the public realm as 'active and good citizens' (Arendt 1958). Yet the very distinction between formal and informal, as well as the understanding that informal firms need to transition to the formal, is misleading by definition. Often, firms are neither wholly formal nor informal but display varying levels of formalization (De Castro et al. 2014; Williams and Shahid 2016; Bruton et al. 2012). This distinction is even more problematic in the context of women entrepreneurship, whose entrepreneurial choices are shaped by social institutions and cultural norms. The literature on women's participation in the informal economy remains conceptualized within a normative 'preferences' framework, aligned to their distinct socio-cultural interests (DeTienne and Chandler 2007) or 'community-mindedness' (De Vita et al. 2014). In this paper, we argue that this conceptualization not only overlooks how preferences are embedded in, and reflect, wider social and cultural norms; we also argue that the emphasis on rational and ethical goals of formalization overlooks the specific constraints women face and the oppressive contexts in which they work.

Unlike their male counterparts (Williams 2009), many women entrepreneurs in developing countries operate within the informal economy neither out of choice nor as a path to formalization, but as a way to position themselves within contexts shaped by norms and expectations around roles and family (Babbitt et al. 2015; Williams and Gurtoo 2011). Consequently, their positioning within the informal economy changes dynamically over time, for example by the need to improvise their business status in line with family, gender and other (e.g. caste) expectations (Xheneti et al. 2019a). The idea of engagement in entrepreneurial activities in the informal economy as an 'opportunity' incorrectly portrays the nature of women entrepreneurship in developing countries, which is more typically characterized by the need for survival and to support livelihoods. This portrayal downplays the realities of women's business choices and decisions in these contexts, where contingencies such as environmental risk, economic instability, social conflict and family morbidity are the norm (London et al. 2014). Moreover, the depiction of formal-informal status-in which the formal is associated with social and economic legitimacy and the informal as secondary, incomplete and unvirtuous-neglects the social challenges and cultural constraints within which women entrepreneurs operate (Ramani et al. 2013; Williams and Gurtoo 2011). Hence, the idea of business opportunity or growth and success through formalization raises not only legitimacy conflicts between women's roles and identities, it raises further questions about the ethical nature of formalization itself and its implied virtuous outcomes.
To consider these questions, our goal in this paper is to explore the nature and the context of business formalization among women entrepreneurs in a developing country context. We use insights from institutional theory and sensemaking to understand how women entrepreneurs engage with the process of formalization, what that means to them and their experiences in the informal economy. We explore these questions in the context of Nepal, a country with the highest participation of women in the informal economy within South Asian countries (ILO Nepal 2014). Overall, women's literacy in Nepal is just over $40 \%$ (Trading Economics 2016), with age, caste and spatial variations within the country. For example, $70 \%$ of women between 40 and 44 years old have no education whatsoever, while over $40 \%$ of women aged 20-24 years old are married before the age of 18 (UFPA 2017). The stratified nature of Nepalese society in terms of unequal power relations and social-cultural norms prescribing the position of men and women in the society (ILO 2005) have directly influenced the characteristics of, and attitudes towards women-owned ventures. As such, the expectation of women's economic contribution is, at best, secondary and more commonly ancillary to that of men.

We report on the findings of a research project undertaken in 2015, which examined formalization among women entrepreneurs in three different cities in Nepal-Kathmandu, Pokhara and Biratnagar. Our findings reveal the complexity of how women entrepreneurs made sense of formalization and its perceived value. We identify three distinctive groups of women with different interpretations of formalizationbusiness sustainability, livelihood sufficiency and strategic alignment - where each interpretation reflected distinctive life stages and experiences in the (in)formal economy. In line with these interpretations, the women in our study adopted a range of strategies towards formalization-such as postponement, rejection, progression or re-entering the informal economy - suggesting that decisions to formalize businesses were cyclical, rather than linear, and improvised according to women's subjective understandings of their situations, rather than rational in an objective sense. These decision strategies also revealed how women navigated through the socially gendered perceptions towards them as women in business. Their decision-making processes thus helped to expose a double bind of virtue, of acting within socially prescribed roles and the need to develop successful businesses.

Our research contributes to the literature on formalization and women entrepreneurship in the informal economy in four ways. First, our findings contribute towards developing alternative conceptions of the value of formalization and its ethical implications that account for the way in which the complex dynamics of socio-cultural norms provide cues to women's sensemaking of, and their choices in, the (in)formal economy. Second, we problematize the normative idea 
of a formal-informal continuum as one that belies the lived experiences of women and fails to account for the different dimensions of informality. Third, we contribute towards debates on the contextual embeddedness of (women's) entrepreneurship, highlighting the role of social capital. Finally, our findings have implications for governmental and international development policy by highlighting factors that facilitate formalization. Overall, we provide a nuanced view of women's formalization decisions that supports the development of more realistic models of business formalization that are relevant to women in the developing country context.

\section{Formalization of the Informal Economy}

Formalization of the informal economy has been pursued as an important policy goal to promote inclusive growth and enhanced business performance in developing countries (ILO 2014). Formalization policies are advocated as tools to provide greater support to informal entrepreneurs through the legitimacy and the added social protection gained from compliance with formal institutions (ILO 2014). Formalization is considered as an ethical decision, while informality is seen as unethical and temporary, exposing individuals and firms to various forms of vulnerability (Ramani et al. 2013; Adhikari 2011). Most formalization policies have focused on improving the business regulatory infrastructure through simplifying business registration processes and lowering registration costs (Bruhn and Mckenzie 2014). The perceived financial and transactional costs associated with firm registration are usually seen to prevent informal entrepreneurs from becoming formal (De Soto 1989) while the perceived lack of relevant benefits compared to costs means that informal firms make a rationale choice to remain informal (Maloney 2004). However, despite the implementation of various reforms, informality continues to persist (Andrade et al. 2014; De Mel et al. 2013; Bruhn and Mckenzie 2014). Arguably, a simple, rational cost-benefit evaluation (De Mel et al. 2013; Perry et al. 2007) does not adequately explain formalization decisions. Not only does it reflect masculine representations of informality and formalization decisions, it also overlooks the contextual and nuanced nature of the informal sector in terms of its appeal as well as its constraints (Xheneti et al. 2019b).

To explain the persistence of informality many scholars (North 1990; Webb et al. 2009) draw on institutional theory to argue that even if informal entrepreneurs operate outside formal institutional boundaries, they still engage in activities that conform to informal institutional logic (social norms and beliefs), through which they gain social acceptance in many developing countries (Webb et al. 2009; Williams and Shahid 2016). At the core of the institutionalist explanation is an asymmetry between formal and informal institutions which conceptualizes informality along a formal-informal continuum.

Arguably, it is an asymmetry that overly simplifies the myriad choices, dynamics and evolving realities-as well as the differing risks and uncertainties-that informal entrepreneurs face (De Castro et al. 2014; Williams and Shahid 2016). For instance, in the Dominican Republic De Castro et al. (2014) observe that rather than making a simple or linear choice, entrepreneurs in the informal economy often make multiple strategic choices around their entry to the formal economy. In addition to costs, complexity and lack of information, the fear of being detached from the social environment greatly influences formalization decisions. Consequently, entrepreneurs in the informal economy strategically select what is seen as an acceptable level of registration, highlighting the greater importance of subjective norms and the need for social acceptance than the traditional literature suggests. Williams and Shahid (2016) argue that in developing countries entrepreneurs operate interstitially along a formal-informal continuum while in Mexico, McKenzie and Woodruff (2007) find that formalization is not seen to be relevant to business growth at all.

Thus, ethical implications of formalization decisions need to account not only for formal institutions and regulatory compliance, but also for the contexts, realities and constraints faced by those who choose to operate informally. By assuming that entrepreneurs are affected by and respond to institutions in homogenous ways, there is a risk of overlooking how institutions are differently interpreted and experienced by entrepreneurs, according to their differing life circumstances and local situational contexts. For example, Uzo and Mair (2014) observe how the overlapping and ambiguous nature of formal and informal institutions, along with the conflicts that arise between them when trying to apply macro-level rules to the local context, lead to entrepreneurs strategically bending formal institutions in line with socio-cultural customs and rules.

In order to understand these micro-level processes and the role of human agency in enacting decisions within a particular institutional and socio-cultural context, we argue that a sensemaking approach offers more explanatory power as it allows us to explore the subjective interpretations of the cues within the institutional environment (Weber and Glynn 2006; Scott 2003). Our approach accepts the important role that institutions play in providing cognitive frames, internalized through socialisation processes (Weber and Glynn 2006; Scott 2003). However, it also emphasizes the subjective internalizations of institutions and the situated social interactions in explaining individuals' meaning making (Weick 1995). This is particularly pertinent in the case of entrepreneurs within the informal sector, and particularly those who are most marginalized (Longondjo Etambakonga 
and Roloff 2020), such as women, who form the focus of our research.

\section{Women Entrepreneurship And Formalization Decisions}

Women's participation in entrepreneurship has grown considerably in recent years (Brush et al. 2009), and they are making significant contributions to social and economic development (De Vita et al. 2014). Despite this, women entrepreneurship is seen as inferior to that of men in terms of sectoral choices, business performance and size (Marlow and McAdam 2013), highlighting enduring gendered conceptualisations of entrepreneurship (Bruni et al. 2004), often evident in a binary approach to entrepreneurship research that focuses on the differences between women and menowned ventures (Ahl 2006). Recognizing that entrepreneurship is a gendered phenomenon (Marlow and McAdam 2013; Ahl 2006), feminist scholars have sought to problematize wider institutional contexts, particularly in relation to the deeply rooted values, norms, and beliefs about gender and how these shape women's choices, identities and experiences (Xheneti et al. 2019b; Marlow and McAdam 2013; Clark Muntean and Ozkazanc-Pan 2015).

While socio-cultural norms and expectations influence both men's and women's business choices, those that prescribe female behaviours and roles have very different effects. The way women entrepreneurs make sense of their engagement in entrepreneurial activities and their contribution to their lives and households is consequently very different to men. Women often downplay their entrepreneurial identities and business success to adhere to socially expected norms regarding their behaviour and roles (Grant 2013). For many women, the image of a successful entrepreneur is incompatible with their prescribed roles, leading to tensions and conflicts about the destabilising effect business success can have on families and local community structures (Grant 2013). While many women may aspire towards success, there is little expectation that they will pursue a successful business career: it is argued that to do so jeopardizes their status and reputation at family and social levels (Rouse et al. 2013). For women therefore, business entry, growth, stability and exit make sense only if they fit with social expectations, values and norms.

These deeply rooted values and norms are further manifested in the informal economy. Women are not only overrepresented in the informal economy (Ramani et al. 2013), they also have lower business registration rates than men and are less likely to see the value of formalization (Kabeer 2012). Existing literature emphasizes women entrepreneurs' preference for choosing informality as a way of managing home and family responsibilities (Chant and Pedwell 2008), to reduce the risks associated with business locations controlled and dominated by men (Adhikari 2011) and to avoid exposure to formal institutions (Bennett 2009). This emphasis downplays the emotional and cultural context of their decisions, failing to address the deep, structural barriers to their economic inclusion and the rich contribution women's enterprises can make (Babbitt et al. 2015; Fonchingong 2005).

Expectations about women's mobility or with whom they should and should not interact can influence their relationship with customers and suppliers (Meagher 2013). This not only impedes women's ability to develop networks beyond family and friends that might enable them to be more responsive to market demands and changes; in the long run it can also influence business growth and formalization (Mitra 2005; Lindvert et al. 2017). Social networks, including family, school-based connections and local identities, can provide women with the support needed to initiate small, informal enterprises, but they can also act as significant constraints on growth potential and formalization by fostering tacit dependencies. Should women's informal enterprises actually expand or eventually formalize, it is the kind of support that can be withdrawn through a loss of common identity, possibly increasing their vulnerability at critical, transitional stages of enterprise development (Grant 2013). Similarly, the socialization of women from childhood to accept prescribed roles has a direct influence on the nature of their ventures and on their choice of sectors in which to work, usually those with limited growth potential and opportunities to formalize (Babbitt et al. 2015). Women entrepreneurs often face a number of further constraints, such as access to credit which limits their entry to the formal sector (Babbitt et al. 2015).

This is important within the context of formalization, which is depicted as the logical end state for anyone wanting to develop and sustain their business (Bennett 2009). For women this progression represents various risks, including a loss of networks, traditional roles, status and identity, rendering success more like betrayal than achievement (Neves and Du Toit 2012). Further evidence suggests progression can delegitimize traditional social positions as a result of changed status due to success (De Vita et al. 2014). Others suggest formalization can devalue important social networks which operate on shared interests and mutualities that are crucial not only to the functioning but also to the survival of many communities living in precarious conditions (Viswanathan et al. 2014). As Rouse et al. (2013) argue, women's entrepreneurial preferences do not necessarily reflect free choices: they are often manifestations of unjust social outcomes. These concerns point to the need for alternative conceptions of formalization that take into account women's social contexts and the ways in which they make sense of formalization. 


\section{Informal Economy in the Context of Nepal}

The vast majority of the Nepalese population works in the informal economy. The most recent Labour Force Survey reports that around $62 \%$ of the economically active population works in the informal sector with a higher number of women (66.5\%) than men (59.7\%) (CBS 2019). The informal economy is characterized mainly by craft and related trades $(80.3 \%)$ and service-related activities (54.1\%) (CBS 2019), both disproportionally featuring women. The development of formal entrepreneurial activities in Nepal has been impeded by the lack of access to finance and weak infrastructures (Afram and Del Pero 2012), other factors including labour migration, land fragmentation and a significant increase in the size and the nature of the informal economy (Sharma and Donini 2012). Not surprisingly, Nepal is ranked 105th out of 189 countries in the 'Doing Business Index' (World Bank 2016), and 144th in the Human Development Index (UNDP 2015). Its relatively poor position also reflects the effects of ten years of Maoist conflict (1996-2006), the political instability that ensued this conflict, along with problems of corruption in public sector institutions, all of which has hampered efforts at economic growth (Dix 2011). The Maoist conflict had a significant impact on women's engagement in the informal economy because of the displacement of men and the consequent need for women to assume men's traditional household roles (Menon and Rodgers 2015). Still, women have struggled to garner trust in their roles as business women not only from customers, but also from formal financial institutions, suppliers and others who question their ability - and even their legitimacy — to be business people (Bushell 2008). Despite the restrictive effects of social networks and a lack of supportive government policies, promoting the formalization of women's informal business activities remains a key policy goal to strengthen Nepal's economic development (ILO Nepal 2014).

The regulatory framework governing formalization processes in Nepal is quite complex. According to the country's 1992 Enterprise Act, enterprises must be registered with central government agencies, namely the Department of Cottage and Small Industries (DCSI) or the Department of Industries (DOI), depending on the size of the investment. Enterprises with less than 10 million rupees $(\$ 1=$ Rs. 120$)$ of fixed assets should register in the DCSI; those with fixed capital above this level with the DOI. For a business to operate legally, it must register with at least one government authority. In addition to the DCSI or DOI, businesses can register locally, with a Village Development Committee (VDC) or a municipality office (ILO 2005). Firms with less than Rs. 20 million annual turnovers must register for a Permanent Account
Number (PAN), whereas those with over Rs. 20 million are liable for Value Added Tax (VAT) and must register with the Department of Inland Revenue. Based on the nature of products or services, other types of licenses are also needed. For instance, firms operating in the food industry need to apply for a license from the Department of Food Technology and Quality Control. Rules regarding bank loans are similarly complex, access to which reflect Nepal's traditional social values in terms of land title and inheritance (Xheneti et al. 2019a).

\section{Methods}

This paper is based upon a qualitative research project about women's transitions into the formal economy in Nepal. To realize our aim of a more nuanced understanding about women's experiences of formalization means our approach is interpretative in nature, in search of the meanings and significances people attach to their social worlds (Geertz 1993). Our interpretative approach is also guided by the principles of social feminism, that recognise the life-long socialization processes and unequal economic power relations that shape gender differences (DeTienne and Chandler 2007; Clark Muntean and Ozkazanc-Pan 2015). Our focus on businesses operated solely by women is in response to the dearth of studies that explore women's informal enterprises in their own right (Brush et al. 2009), with most research based on either male or mixed gender samples (Andrade et al. 2014; De Mel et al. 2013).

\section{Sampling Strategy, Data Collection and Participants}

A stratified sampling strategy was designed for the selection of women entrepreneurs on the basis of diverse enterprise dynamics as reported by the Labour Force Survey (CBS 2008). Three different cities in Nepal—Kathmandu, Pokhara and Biratnagar-were selected for this study. Kathmandu is the capital and sits in the central region of the country. It is the main destination for most work migrants in Nepal, particularly from rural and remote districts. Pokhara is Nepal's tourism capital, situated in the country's western region while Biratnagar borders India and serves as the main economic and service hub for the eastern region. While these cities may not be wholly representative of Nepal's unique spatial and demographic character, they were purposively selected because of their diverse spatial and economic situations and the range of entrepreneurial activities undertaken by women.

Our final sample consisted of a total of 90 interviews: 30 interviews were conducted, with 23 women drawn from the informal economy and 7 from the formal economy, in each city. The semi-structured interview focused on a range of 
topics, including motivations to start a business, the range of economic, socio-cultural and institutional factors that affect women's choices in the informal economy and future aspirations associated with current entrepreneurial activity. Interviews lasted between 30 and $100 \mathrm{~min}$ and were conducted at the participants' business premises. Three research assistants conducted the interviews between December 2014 and March 2015. Interviews were undertaken in the Nepali language, transcribed and then translated into English. Data were loaded into NVIVO 11 for analysis. Pseudonyms are used throughout this paper to protect participants' identities.

In terms of economic activity, many of the participants in Kathmandu (53\%) and Biratnagar (37\%) were engaged in service-based ventures, including tailoring, beauty parlour and café businesses. In Pokhara, $43 \%$ of the participants were engaged in trade-based ventures, such as grocery, readymade clothing and cosmetics businesses. Most participants were aged between $31-40$ years old. Education levels varied across the three study sites: the average literacy level was $60 \%$, comparable with the national average of $58 \%$ (CBS 2008).

\section{Data Analysis}

We used a sensemaking approach to analyse our data, to explore how women thought about formalization and how this influenced their thinking and decisions whether to formalize or not. Sensemaking is described as a retrospective process of constructing meaning from novel, ambiguous situations (Weick et al. 2005). The process of making sense involves people summarizing past events and building plausible accounts that impose order and meaning into a situation. The process enables people to manage competing and conflicting sources of information often with ethical implications (Ness and Connelly 2017). Sensemaking is also seen as a social activity rather than an individual phenomenon, whereby people construct meaning through their close interaction with others (Weick 1995).

Sensemaking occurs through a sequence of three core processes: scanning, interpreting, and responding (Thomas et al. 1993). Scanning involves observing the environment and gathering information, necessary for interpreting and responding (Thomas et al. 1993). Interpreting concerns deciphering information according to certain schemes or rules in order to create meaning (Gioia and Thomas 1996) and sits at the heart of the sensemaking process. Responding is about acting based on that interpretation (Thomas et al. 1993). Cardon et al. (2011) suggest sensemaking is particularly valuable in studying entrepreneurs as they regularly face ambiguous situations in which knowing what is being scanned and how this is interpreted helps to better understand their decisions and actions.
Our approach to data analysis was guided by these three principles of sensemaking in terms of: first, understanding the experiences of women in the (in)formal economy. Second, how these experiences led to certain interpretations of formalization and third, how these interpretations shaped decisions and actions with respect to formalization. 'Within' interview analysis was combined with 'across' interview analysis to allow an understanding of women's accounts within their own context and across women's experiences (Gummesson 2000). Based on how participants scanned their business and personal environments, our analysis and coding of the data highlighted three distinct ways in which women interpreted formalization. First, those women who considered the salience of their experience in the informal economy, the economic and social benefits of operating in the informal economy and the importance of weak networks, interpreted formalisation from a business sustainability perspective. Second, those that were content and satisfied operating in the informal economy, perceived formalization as economic and emotional loss, and access to support from local communities and strong networks to deal with the legal aspects of their business, interpreted formalization from a livelihood sufficiency perspective. Third, those women who saw formalization as a good fit with the development of their business, as a good option to comply with the rules and demands and were able to access support from weak networks in getting information on registration and business registration, adopted a strategic alignment perspective to registration.

Based on this, in the second stage of data analysis we were interested in how participants' interpretations impacted on their decisions to formalize. Those that were uncertain about their business and the barriers to registration tended to postpone their decision about formalization. Those that felt formalization did not fit with their current family situation or was incompatible with their social roles rejected it. For some, the decision to formalize not only depended on the perceived value of formalization in expanding their businesses; it often reflected whether participants perceived their decision to be voluntary or not. In these examples, women's decisions were strategic and dynamic, either progressing (i.e. registering) or deprogressing (deregistering) their businesses. In the final stage of data analysis, we sought to explore the extent to which life course and socio-cultural context might explain these patterns and heterogeneous experiences identified in the data. The different stages of data analysis from initial codes to development of themes are illustrated in Table 1 and presented in the next section.

\section{Findings}

Our data highlighted the different ways in which participants made sense of their individual, family and life circumstances within the complex socio-cultural context of 
Table 1 Emergence of analytical codes and initial codes from the raw data

\begin{tabular}{lll}
\hline Analytical codes & Initial codes & Raw data
\end{tabular}

Business sustainability Experience in the informal economy

Economic, social and emotional benefits

Support from strong and weak networks
Karuna (Kathmandu, Tailor, 1-5 years in business, Illiterate, Married with school-age children)

I opened this shop immediately after finishing my training. I was inexperienced and damaged many outfits so had to pay the price of the clothes. Now, I am confident and my customers are also happy with me. As I am more confident, I am thinking about registration

Bhawana (Biratnagar, Chicken Farm, 1-5 years in business, Secondary education, Married with children in higher education)

I am aware that business has to be registered but I have not done that. Our business is small and early phase and we are still learning from it. I started it with my friend's advice. Once we are certain and it is growing, I will discuss with my friend

Maya (Kathmandu, Woollen products, $1-5$ years in business, Secondary education, Married with school children)

If I register, I will be known, my business will be known. Once known, I will get more access to the wider network of workers, and also suppliers. This will help me get big orders

Menuka (Biratnagar, Clothing store, 1-5 years in business, Higher secondary education, Married with school age children)

I want to register my shop so that I can access loan and expand my shop. This will help me expand by bringing clothes of latest designs. Registration is also important to get a good supplier

Chandra (Kathmandu, Food production factory, Less than 1 year in business, Illiterate, Married with school age children)

My trainer had informed us about the registration, and she also mentioned where we could register. I am thinking about it

Mina (Pokhara, Clothing store, 6-10 years in business, Secondary education, Married with pre-school children)

I talked with a neighbour sister about the registration. Her shop was raided by government officials. She had not registered her business them, but then registered later. I knew about that incident and she also told me that it is important to register to operate freely without any fear 
Table 1 (continued)

\begin{tabular}{ll}
\hline Analytical codes & Initial codes \\
\hline Livelihood sufficiency & Content and satisfaction in the informal econom
\end{tabular}

Emotional and economic loss from formalization

Operating among communities in the informal economy and receiving support from strong networks to comply with the legal rules

Perceptions associated with registration
Raw data

Sarita (Kathmandu, Cafe, 1-5 years in business, Illiterate, Married with children in employment)

I have been running this café and fulfilling all my responsibilities without registering. I had previous cafes, which were not registered as well. We educated our children, my daughter got Married, and I trained my son with all the money from this unregistered cafe. We are old now, I will continue without registration as long as I can, and after that our sons will look after us

Gunjan (Pokhara, Tailor, 1-5 years on business, Secondary education, Married with school-age children

The business is sufficient for me as I have been able to pay rent and contribute to the household. I have reached here, which I had not thought I will

Sumitra (Kathmandu, Pottery, More than 10 years in business, Illiterate, Widow with grown-up children)

My husband was ill for 17 years and then, he died. With great difficulties, I am managing home and business as all came on my shoulder. I had to provide for them. I used to have many items, such as bamboo and straw, but my son's death nine years ago has affected me a lot. I don't care much about the business because of the stress, it will continue as it is. I cannot think of anything else

Durga (Biratnagar, Ice cream shop, 6-10 years in business, Illiterate, Married with children in employment)

I know that when we register we can run freely without any fear of being monitored. But every year, I have to pay tax to the government, if I register

Anamika (Biratnagar, Parlour, 1-5 years in business, Secondary education, Married with school-age children)

I know that business has to be registered, but other shops also have not registered, so I ignored the registration. If others had registered, I would have also done so

Kopika (Pokhara, Food production, 6-10 years in business, Primary education, Married with pre-school children)

I asked my neighbour sister, from whom I learned to make this food, to allow me to use the label of her firm on my packaging. She consented to give me to use the label of her firm

Kamala (Kathmandu, Parlour, 6-10 years in business, Secondary education, Married with school age children)

I don't have a big investment in this business. It is very small. I was told by my friends that there is no need to register when it is very small

Neha (Pokhara, Butcher shop, 6-10 years in business, Lower secondary education, Married with school age children)

Yes, I have registered with the Meat Business Association. This shop was registered in the same association since it was run by my in-laws. I joined full time just eleven months ago when my mother-in-law fell sick. I know nothing about other registration. We were told that it is good to register here in the association so we registered there. It makes sense as we run meat business 
Table 1 (continued)

Analytical codes

Strategic alignment
Initial codes

Good fit for business development stage

Safe option to comply with the rules and demands

Support from weak networks in getting information on registration and registration process
Raw data

Aruna (Kathmandu, Parlour, More than 10 years in business, Higher secondary education, Married with schoolage children)

For the initial three years, I did not register it thinking that I may be able to run it well or not. Then, I had settled in this business for a long time and I knew it would run for more years, and I also wanted to extend it. So, I decided to register. Initially, I registered in the DCSI and then in PAN

Babita (Biratnagar, Parlour, 1-5 years in business, Higher secondary education, Married with pre-school children)

I have registered in DCSI office. The main benefit of registering is that I can give away the training certificates to my trainees. The government takes care of our business if it is registered. My family also suggested me to register so I registered

Prakriti (Kathmandu, Office supplies store, 6-10 years in business, Primary education, Married with school-age son)

We had to register because the college administration told to get PAN number for the bills. Without it, we could not do any business with them. They were providing us with big orders of Rs.60,000 every season. Registration was compulsory to work with them

Prerna (Pokhara, Grocery store, 6-10 years in business, University education, Married with pre-school children)

Yes, I have registered in DCSI. They had an announcement about registration. I was worried that I will be fined and have to close my business. I went and registered immediately

Namrata (Kathmandu, Parlour, 1-5 years in business, Higher secondary education, Married with pre-school children)

I had heard we should register any business. This idea was given to me by my friends in the bank. They had said if I register it would be easy to access loan. So, I registered the shop

Swasti (Biratnagar, Café, 1-5 years in business, Secondary education, Married with pre-school children)

I have registered this hotel but have not got the PAN yet. I came to know about the registration through my friends who are involved in different businesses. So, we went for the registration together 
Table 1 (continued)

\section{Analytical codes}

Postponing registration
Initial codes

Uncertainty with the business in the informal economy
Barriers to registration

Fit with current family situations

Incompatibility with social roles

Raw data

Devika (Biratnagar, Accessories Shop, More than 10 years in business, Secondary education, Married with preschool children)

I want to register my business. But, there is no good business. The shop is not so big. When the shop becomes bigger I will register. After registration, we will have to pay tax but when there is no good income, how can I pay the tax?

Ramita (Pokhara, Parlour, 1-5 years in business, Secondary education, Married with pre-school children)

I have not registered as I am busy with my business. It is also very new so we don't know it will run well. My friends and I have decided to go there one day

Mahima (Kathmandu, Tailor, 1-5 years in business, Secondary education, Married with school age children)

I once tried to register and went to the Village Development Committee. They told me as it's a small tailor shop and come back later. But, then I went again and they asked me to get papers. I then decided to leave for now

Sabita (Biratnagar, Grocery, 6-10 years in business, Secondary education, Married with grown-up children in government employment)

I want help from the government. I have nothing to show as a property. I can't show papers of my house as it is not in my ownership. After my husband return from abroad we both will decide what to do about the hotel

Jaya (Kathmandu, Cow farm, More than 10 years in business, Illiterate, Married with grown-up children)

I am satisfied with this cow farm. I cannot extend and I don't want to extend. I don't need to do anything. I will run this as long as my health will allow. I have no plans to register this business

Grishma (Pokhara, Candle making business, 1-5 years in business, Primary education, Married with a grown-up children)

Both, my husband and son do not work as my husband has been ill for many years and my son is deaf and unable to speak. My household situation has put the entire burden on me and my business has been supporting us. Running my existing business and looking after my husband and son are the only priorities for me

Usha (Kathmandu, Cafe, More than 10 years in business, Illiterate, Married with grown-up children)

I don't have plans to register; it is fine as it is. I am old and I want to go on a pilgrimage. My sons also scold me that I run cafe. They say that they will look after me and I should leave everything and relax at home

Nanu (Biratnagar, Parlour, 1-5 years in business, Primary education, Single woman)

I am not married and I live with my mother, and brother's family. When I opened this parlour, my budget was small. There are not many products in the shop. I do not have any interest to expand or do anything at this stage; in future, if I am married I will think about it 
Table 1 (continued)

Analytical codes
Progressing or re-
entering to the informal
economy

Initial codes

Voluntary/Involuntary decision

economy
Business expansion and progression

Rethinking of registration status
Raw data

Sujan (Pokhara, Pharmacy, Less than a year in business, University education, Married with pre-school children)

I have registered, as it is mandatory to run shop like ours. Without a proper license, we cannot run a pharmacy store. Our previous shop in the village was not registered, but when we decided to move to the city, we registered even before opening our shop

Ratna (Kathmandu, Tailor, More than 10 years in business, Secondary education, Married with school age children)

I spent Rs. 200, 000 in the training so I knew I have to do something to recover the costs. I did not want to register my shop, as others also have not registered their business. However, I wanted to take trainees to earn extra money and use them to sow the clothes. Trainees started to demand certificates so I registered

Deepti (Biratnagar, Tailor, 1-5 years in business, Secondary education, Married with school-age children)

I want to sell my products in international market. I am involved in many organisations. They have assured me that they will support in exporting my products abroad. I have the confidence to grow beyond here. I will be getting

Kripa (Pokhara, Montessori Training Centre, 6-10 years in business, University education, Married with schoolage children)

I learned the process of the opening of the training centre. Then we registered, managed the lab, then we started teaching. As we were growing, we went and registered for PAN and VAT. Now, we are thinking of getting membership of other organisations to expand our business further

Sita (Kathmandu, Grocery store, 1-5 years in business, Higher secondary education, Married with pre-school children)

One year after buying the shop, I registered. I have been paying Rs. 3,800 tax every year since the registration. There is no benefit from the registration. I only got the gas from the dealer. There is a loss because I have to pay tax. I am thinking of closing and opening another shop without registration

Padma (Pokhara, Incense making, 6-10 years in business, Secondary education, Separated with school-age daughter)

While I did the pickle business, I had registered and paid five thousand rupees. However, it was of no use, I did not get any benefits, and all money was wasted. I closed that business and started this one. I am running this one from home so that I do not have to register
Nepal, revealed through a number of different perspectives of formalization-business sustainability, livelihood sufficiency, and strategic alignment. Table 2 highlights participant's interpretations of formalization in terms of personal, business and social characteristics.

\section{Business Sustainability}

A number of women in our sample anticipated that formalization of their business would lead to greater sustainability in the future because of the economic and social benefits that legal visibility would bring. Many participants 


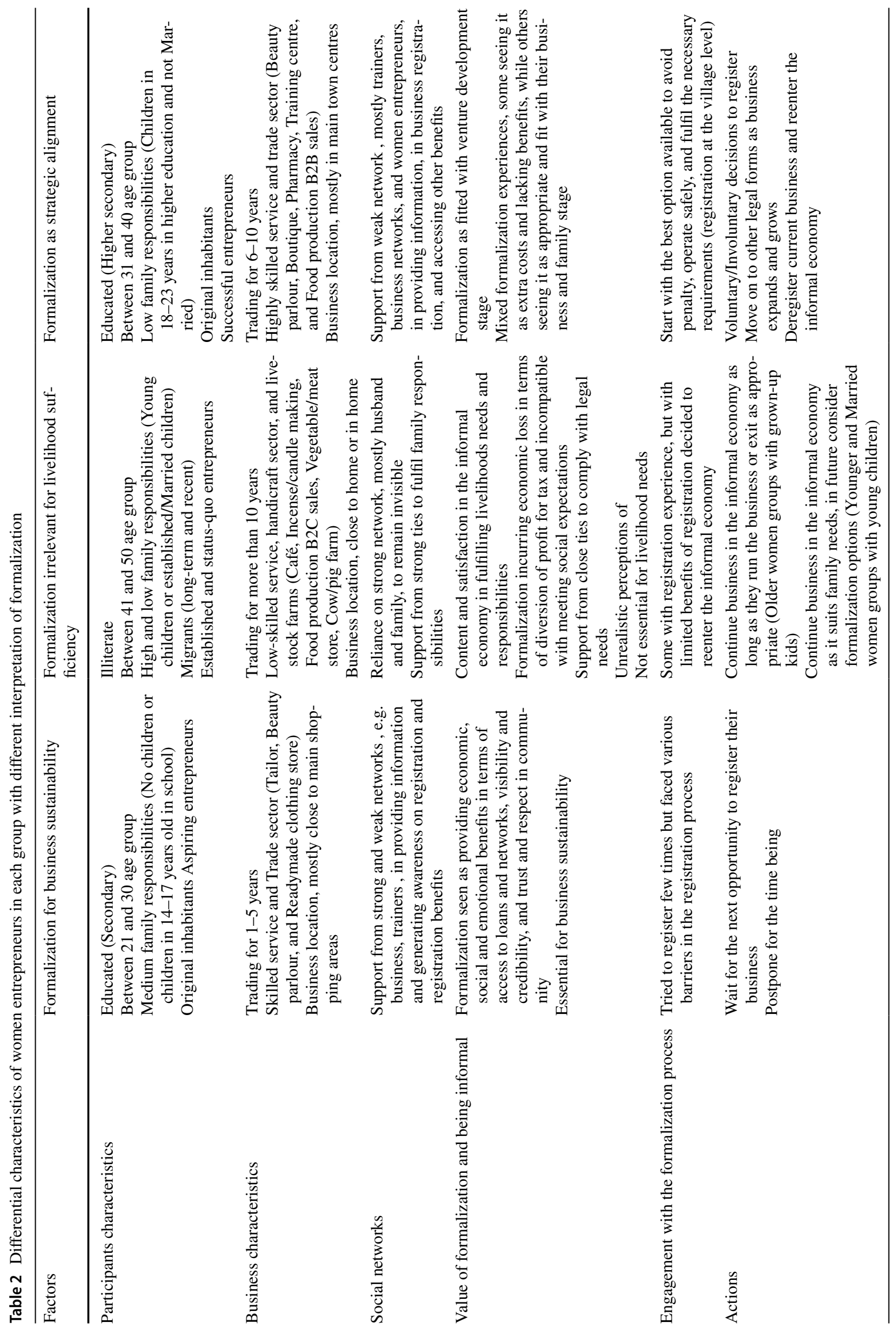


held the view that registration would provide their business with the freedom to work without the risk of government scrutiny as well as reduce the fears and costs of being informal. These costs included the confiscation of goods, fines for improper operations and even shutting their business down. The perceived economic benefits mainly included positive business outcomes, including gaining access to loans, suppliers, customers, to prospective clients and employees, and receiving recognition/support from government agencies and other organisations. Access to finance, for example, was associated with business expansion, attracting customers, employees and suppliers, as well as being better able to differentiate business activities from other competitors. In the highly saturated informal markets of Nepal, formalization is seen as an important opportunity to create competitive advantage. Devika, who runs an accessories store in Biratnagar explained: 'Registration will help me with access to loans. Once I have more money, I will be able to expand this shop'.

Despite these perceived economic benefits of formalization, most women emphasized its social benefits, including the improved social status that resulted from the increased visibility of their business and recognition in the community. Rekha, who runs a soft toy-making workshop in Pokhara stated:

Registration is good as we can do business openly. The workshop will be visible to people, we will get more customer and trainees; the business will be good. People from this area will know about my business.

This idea of gaining visibility and becoming known highlights a perception that registration has a transition effect, through which a business can gain credibility and access to new networks, new customers and other resources. It can also gain legitimacy and respect to women entrepreneurs and their business within the local community, especially if the benefits from their business spill-over to others in the community, for example by offering employment or necessary goods and services. Laxmi, a divorced woman who moved from Biratnagar to run a soft toy workshop in Kathmandu, described how she thought formalization might help her business gain visibility and further respect from others if she was a 'registered' business and a 'responsible' citizen paying taxes. For women like Laxmi-whose divorce runs counter to social norms in the Nepal context, by stepping outside her home life and creating a new identity as a business woman-formalization is about much more than a cost-benefit decision or gaining legal status. Laxmi plans to register in order to create a sustainable business that her daughter can take over in the long run. Because women in Nepal often lack identity other than as a daughter, a wife or mother, Laxmi wants her daughter not to be exposed to this constraint:
I want to teach my daughter this skill and involve her in this business slowly. I would like her to be independent in life.

Women interested in formalization from a sustainability perspective also talked about social networks as a source of knowledge about registration and as exemplars of registration benefits. Often beyond their immediate networks, women spoke about the importance of links to training providers, suppliers and one-off business contacts as reliable sources of information about registration and also in relation to accessing potential workers, suppliers, contractors and customers. Formalization thus makes sense in this context, as it enables access to practical support as well as more experienced businessmen and women who can assist in the registration process. Both strong and weak networks were important in influencing women's perceptions of formalization but the women who benefited most from these links were those who ran their business outside of the home environment or traditional family structures. It appeared that these networks better facilitated the information and support required to see the positive meaning and value of formalization.

\section{Postponing Formalization}

Despite some women's desire to formalize as a way to ensure business sustainability, our data revealed many stories of deferral or postponement of registration plans for several reasons. For example, the business environment in Nepal presents many hurdles because of the complexity and the requirements of the formalization process for certain types of official documentation, which many women cannot access in Nepali society, as well as wider ambivalence about the value and sustainability of female-run businesses. Formalization was not pursued by these women because of perceived environmental uncertainties and challenges. Some women experienced socio-cultural barriers and constraints from within their households. For example, some needed to ask the male members of their household (husband, father, or brother) or, if in rented accommodation, then a landlord was asked to sign a document confirming their agreement to the women's business plan. Many also talked about how traditional domestic roles and expectations left them with not having the time to complete the registration process, all of which led to the perception of registration as not worth pursuing. Anuradha, who operates a boutique in Kathmandu, talked about her efforts to expand and register her business, highlighting the gender constraints many women face in this context:

I went to apply for a bank loan, but the manager did not trust me. I have a baby face; I am small and look immature. The bank manager did not respond to me 
at all, despite showing him my business transactions. I was told to show business registration papers if I wanted to get a loan...I went back with my father who guaranteed the loan repayment. Only then, I managed to get a loan.

She encountered similar issues when trying to register her business:

I went to register my business but couldn't. As I was renting this shop, I was asked to bring the rent agreement paper from the landlord. I contacted my landlord for the papers, but he refused to provide anything saying that he would not like to be involved in legal issues.

In addition to these gendered constraints, Anuradha highlights limitations in relation to the informal economy itself. People such as landlords may be unable or unwilling to help as they too exist in the shadows of informality, preferring to keep their business activities beyond the official gaze of government. This was a common experience. Some participants who had tried to register their business reported being rejected by the registration office due to the lack of proper documentation, over which they had little control. Others postponed their decision to formalize because of uncertainties about business viability while some were unsure if home-based enterprises had to be registered.

Issues of scale and the prospects of viable separation between business and home pointed to deeper issues about the nature of women's home-based enterprises. As some literature shows, women's home-based enterprises are often based on or linked to their domestic skills and reproductive roles as mothers, carers or educators (Neves and Du Toit 2012), and the blurred boundary between the gendered nature of what work is valued, what constitutes legitimate work and the need for registration for business growth, expansion and sustainability. Some participants who wanted to make their business sustainable intended to wait for a time in the future when the business environment might be more certain, or their enterprises would be sustainable enough to register. The deferral of decision-making highlights the pragmatic nature of sensemaking as a way to (temporarily) resolve conflicting imperatives in rich contextual environments (Weick 1995). The issue centres less on 'what is right?' and more on 'what is right now?'.

\section{Livelihood sufficiency}

Women who viewed formalization from a livelihood sufficiency perspective conceptualized their engagement in the informal economy more as a way to meet complex livelihood needs, expectations and responsibilities, as well as to pursue other goals in terms of contentment and life satisfaction by engaging in an income generation activity. These needs were often perceived to be incompatible not only with formalization but also with social norms which meant women were not expected to spend longer hours on their business than at home. The common perception amongst these women was that there was nothing to be gained from registration because they had already fulfilled a number of life obligations through their unregistered business.

Perceptions of formalization reflected the complex social environment in which participants were embedded. Operating in strong circles of networks comprising family, friends and social groups, those women entrepreneurs who interpreted their experience in the informal economy as 'sufficient' also experienced a lack of positive role models or positive reinforcement and information about the regulatory context. Consequently, they reported knowing very little about the processes or implications of registration and that few businesses in their locality or immediate circle had registered. This gave legitimacy to informality as it helped to provide participants with a strong sense of belonging and commonality among like-minded peers, reinforcing their beliefs that registration benefits were negligible and that continuing in the informal economy was a better option to maintain their livelihoods and household relationships. The strong sense of commonality and access to informal finance and labour that these strong networks provided enabled some participants to be confident about their ability to continue to operate informally. Their confidence seemed well justified. In some cases, the businesses had been running for over ten years and in others, women had found ways to comply with regulatory requirements without the need to register. For example, some women talked about being able to access illicit certificates such as training completion certificates, receipts, or even food safety labels. Participants did not see any issue with this despite obvious risks. Based in Pokhara and running a tailoring business, Neelam stated: 'I haven't registered, and I don't need to. Why pay tax every year? No! Instead I buy certificates from my friend'.

These strong networks and the sense of belonging they conveyed enabled participants to comply with socio-cultural norms, such as expectations about family relations and women's role in society. Compliance is thus performative, in the sense of enacting a gendered and cultural script that is ethical and responsible 'self-making' within the given context (Butler 2005, p. 17), and construal to the sensemaking processes of self-identification (Pratt 2000). It is by remaining 'true' to these norms that it is possible to be able to show interest in business expansion or to put in the extra-long working hours needed to achieve this while maintaining traditional positions. However, in some examples a lack of accurate knowledge about registration contributed to unrealistic perceptions of what the requirements and costs of the process were. For instance, some participants believed that registration required the payment of a one-off charge at 
the beginning of the process, followed by monthly charges during the lifetime of the business. Others were confused about which organizations or government departments were responsible for registering businesses. Dilasha from Pokhara who runs a tailoring shop illustrated this confusion:

I want to register my business in the Christian Association [NGO], in 'Share and Care'. No money is needed to register for 'Share and Care' and they told me no need to register to other places. For tailoring business like mine there is no need to register at the Department of Cottage and Small Industries.

This lack of knowledge contributed to some women's negative views of registration, leading to a mistrust of government and its institutions. Aditi in Biratnagar who manufactures stone pestles and mortars stated, 'No, I haven't registered my business ... I have no faith in government and anything they do'. Trust is an important determinant of regulatory compliance, extending beyond governmental organisations to other groups and social networks to which women feel belonging. Although born Hindu, Dilasha became a Christian and a regular church attender, through which she developed strong social contacts with other women running business activities as well as their business networks, building mutually trusting relationships along the way. For Dilasha, adherence to Church group norms became more meaningful—salient and beneficial—for her business than legal compliance.

\section{Rejecting Formalization}

Many women who interpreted their involvement in the informal economy to be primarily about livelihood sufficiency saw formalization to be irrelevant and the informal economy as a way to balance differing and conflicting expectations. Indeed, the prospect of formalization represented possible conflict between livelihood and household needs/expectations. Romila's account provides a good example of such conflict. Being a widow with two young children, Romila had to start a tailoring venture as the only way to ensure her family's survival. Driven by the need to take care of her children, she located her shop close to her home even though she realized the benefits of more central locations for attracting more customers. However, she was also conscious of the higher demand and costs that a central location would mean in terms of working hours:

We will have to work hard to pay the rent and this will mean that we cannot give more time and attention to our kids.

Romila's story reflects the careful positioning and balancing that many women undertake in order to address the tensions of running a business. Specifically, it highlights the need for women to work hard to make ends meet and the equivocal expectation of not working too hard so as to subvert socio-cultural expectations about women's roles or be seen to neglect family:

Yesterday, we were out the whole day in the market to buy things and it was late in the evening while returning. If we were men we could return late, and nobody would question us for being late. They don't have the responsibility to care for the kids or elders, so nobody bothers if they are out. But we are always thinking about family, like whether the children have eaten, studied, while working and always considering what they will say if we are not on time. To register means we will have to pay taxes, and to pay taxes we will have to earn more money, for which we will have to work long hours. It will be difficult to manage with a registered business.

The normative value attached to business formalization overlooks the practical value that sufficiency represents for women living in this context. Given her particular life circumstances and the Nepalese socio-cultural context, Romila is content with the independence and the self-sufficiency she has achieved, whereby she can take care of her children. Registration benefits have little meaning in this context as it is not relevant to the priorities, demands and life situations of these women.

\section{Strategic Alignment}

In line with the plausible nature of the sensemaking approach (Weick 1995), women's experiences in the informal economy influenced their decisions to register when there was a 'strategic alignment' between their life circumstances and their business situations. These experiences not only influenced women's decisions to register their business, voluntarily or otherwise. They also impacted upon the level or type of formality sought, such as local registration or registration with central government, as well as the perceived positive or negative experience of running a registered business. From participants' accounts, four factors emerged that played an important role in facilitating formalization: (i) the effect of supportive networks; (ii) the stage of development of women's businesses; (iii) demands from suppliers and clients, and iv) fear of penalty.

Our data showed that that social networks are very important to women's business decisions in Nepal. Where strong social networks had a dissuasive effect towards registration as observed in the case of those conceptualising formalization as unnecessary for livelihood sufficiency, weak networks played a more positive role in influencing women in this group to register their business. For instance, some women described how support from networks played an 
important role in sharing knowledge about registration and generating awareness of registration benefits. Support from weak networks was important in raising awareness about formalization and supporting the registration process. These weak networks were often made up of other women entrepreneurs running registered businesses or community activists from various organizations, who provided normative role models. Rojisa, based in Biratnagar and running a handicraft business, explained the role played by another woman entrepreneur, Hemlata, in shaping her registration decision:

I registered my business because of the suggestion of Ms. Hemlata, whom I came to know through the secretary of this area's association. Before, I hesitated, thinking I have to pay tax but she advised me on the benefits and also took me to the registration office in her scooter and helped me to register my business.

Ms Hemlata's help had spill-over effects on other women entrepreneurs. Rojisa added:

As soon as I received my training and started with my business, I was invited to provide training in many places. I felt proud of what I was doing and thought that every woman should do business and not stay idle at home. My prior experience of being informed and supported by Ms Hemlata, encouraged me to do the same with other women by telling them about the benefits of doing business and the benefits of registration.

Rojisa's story illustrates again the importance of trust and credibility in influencing perceptions of formalization and subsequent decisions that expose the social and contextual logic to formalization decisions that transcends simplistic considerations of financial costs alone.

For other women, registration was an instrumental choice, taken voluntarily as part of a clear business development strategy. Bhagwati, who runs a mushroom farming business in Biratnagar, explained that the decision to register her business was also linked to a view that her enterprise had reached a stage where formalization was both apt and necessary:

We registered three months ago... We are expanding and doing well and our sons are also working in this business. They have established a lab to grow seeds for mushrooms, which we sell to other farmers. We also deliver our products to many dealers, so registration became necessary to have receipts and food labels.

While we do not propose anything like a lifecycle model here (for many of the same reasons of avoiding optimalbased decision models), Bhagwati's experience suggests that within the very specific contexts of women's entrepreneurial careers there are times when formalization makes sense because it 'fits' with the stage of business development. Other women entrepreneurs had registered their businesses not out of choice but because of demands from suppliers and clients, or for fear of formal sanction. For example, when suppliers and clients had specific requirements for working with registered business, such as the need to provide receipts or invoices, women had no option but to register their business. In such examples, registration was seen negatively, as illustrated by Sujata who sells kitchenware and other items linked to religious devotion (puja) in Kathmandu:

I registered after I had bought this shop. I had to bring some plasticwares and the supplier demanded the purchase receipt. At the beginning, we registered at the Municipality, then at DCSI, Ministry of Industry and Inland Revenue Office. There is no benefit; it is a loss. We have to pay tax.

This participant explained how she saw the complex process of being registered as a loss because, operating from a homebased shop, meant there was little scope for expansion. She added: 'I don't want to make my house like a department store'. Sujata also explained that her relative success had drawn the negative attention of her landlord, saying: 'The landlord envies me. I face that problem when there is good business, even the landlord envies me'. Others who had registered their business because of fear of penalty usually did so only at the local level, either with the municipality or with the village development committee (VDC), rather than with government departments. Local registration allowed these women to reduce tax fees, to keep a low profile and create a semblance of legality through semi-formality. Hence, formalization was considered as a 'safe' option as they did not have to worry about sanctions, and it fulfilled the demands of suppliers.

However, the perceived losses of registration and the possible need to move to new suppliers, locations or expand their client-base to justify the costs incurred by the process, led some to review their decision and consider deregistering. Leena, based in Pokhara, runs a tailoring business, explained how she did not see her registration status as a fixed thing:

When my business was located in the municipality I had registered, and I was giving training and distributing certificates. I was paying taxes only, there were no benefits. As a result, I moved the location of my business to this village. I don't have trainees and I don't need the registration status.

Formalization is thus a highly strategic decision to meet business needs but which does not guarantee positive outcomes while for some it acted to intensify constraints, in terms of social (family) or locational (limits on their ability to expand) pressures. Where some had formalized and set up larger scale businesses, the exposure to costs such as taxes 
had meant they had subsequently deregistered and relocated their business.

\section{Progressing or Re-entering the Informal Economy}

Those women who had registered their businesses voluntarily did express more satisfactory business experiences and placed greater value on it. For them, the benefits of registration 'fitted' with the current position of their business and their life circumstances. Jyoti, for example, timed the registration and expansion of her clothing store in Pokhara with her changing family situation whereby both her son and her husband could contribute to the business after respectively finishing school and retiring:

The decision fitted with our future plan and changing situation...This meant that we all could work in the business. We were growing, needed wholesalers to get new clothes...Registration felt necessary as we needed PAN number.

Those who registered involuntarily due to pressure from others or without full information about the process tended to see it as a prudent or 'safe' thing to do. Where this did not lead to any benefits, participants tended to have quite negative attitudes towards registration. In some cases, women had either already closed a registered business and started a new one without registering it, or were considering changing their legal status (deregistering). Sunaina, who runs a sewing training centre in Biratnagar, felt sad about operating an informal business because this meant 'running from a good citizen's duties'. However, her experience with business registration in the past led to her decision to close those businesses and run an unregistered one:

I went to register my business. However, I was asked to pay taxes and PAN separately in difference places. Then, I thought... 'why I need to pay tax when I didn't get anything from my previous registered business?' We have no facilities or incentives but we keep on paying taxes.

These examples highlighted that, for some participants, formalization does not have a fixed or universal value but is something that needs to happen at the right time, stage and place. It is a dynamic and strategic process which extends beyond a simple or rational choice event and is structured by complex social norms, networks and expectations.

\section{Discussion}

The aim of this paper was to explore the nature and the context of business formalization among women entrepreneurs in a developing country context. Most literature proposes formalization to be an ethical decision by virtue of its legitimacy with formal institutions or regulatory compliance, and also a logical progression for those businesses that would like to expand and benefit from the provisions related to legal visibility. On the other hand, the persistence of informality in many developing contexts, points to the role of social norms (De Castro et al. 2014), and the legitimacy they provide to those operating outside the legal boundaries of the state (Webb et al. 2009). We argue that both these perspectives with their focus at the macro-level fail to acknowledge the heterogeneity of experiences in the informal economy, the nature of choices (or lack of) amongst different groups of the population such as women, and how they inform subjective assessments of formalization that are contextually embedded in complex socio-cultural settings underpinned by a range of different and perhaps competing values and norms. In this paper, we draw on institutional and sensemaking approaches to consider in greater depth how women entrepreneurs engage with the process of formalization, what formalization means to them and their experiences in the informal economy.

Our findings show that experiences in the (in)formal economy lead to differing interpretations of formalization, reflecting different contingencies such as environmental uncertainties and social conflicts, and leading to different actions in relation to formalization. As such, we show that formalization choices are complex, dynamic, and cyclical, with varied ethical implications for women. Positive interpretations of formalization helped to shape decisions to register or postpone; yet, the registration experience itself often contributed to deregistration. Similar to Bruton et al. (2012), our findings showed that women chose a formalization status that best suited their social needs and circumstances, with registration decisions strategically aligned over time with changing life situations and business requirements in dynamic and complex ways. This indicates that the decision to (or not to) formalize is an ongoing cycle of revisions of interpretation and responses rather than a linear sequence of action (Weber and Glynn 2006) (See Fig. 1). These findings expose insights that complement and add to the current understandings of formalization and women entrepreneurship in the informal economy.

First, our findings provide a better understanding of how women, an over-represented group in the informal economy, conceive formalization and with what implications. While most studies of formalization focus on the macro-level institutional setting, our use of a sensemaking approach with its attention to micro/situational contexts and social interactions that affect decision-making clearly showed the varied interpretations of formalization, depending on the complex dynamics of socio-cultural norms and social mores. Seeing informal women entrepreneurs as a diverse group, populating different entrepreneurial spaces and positions in the 


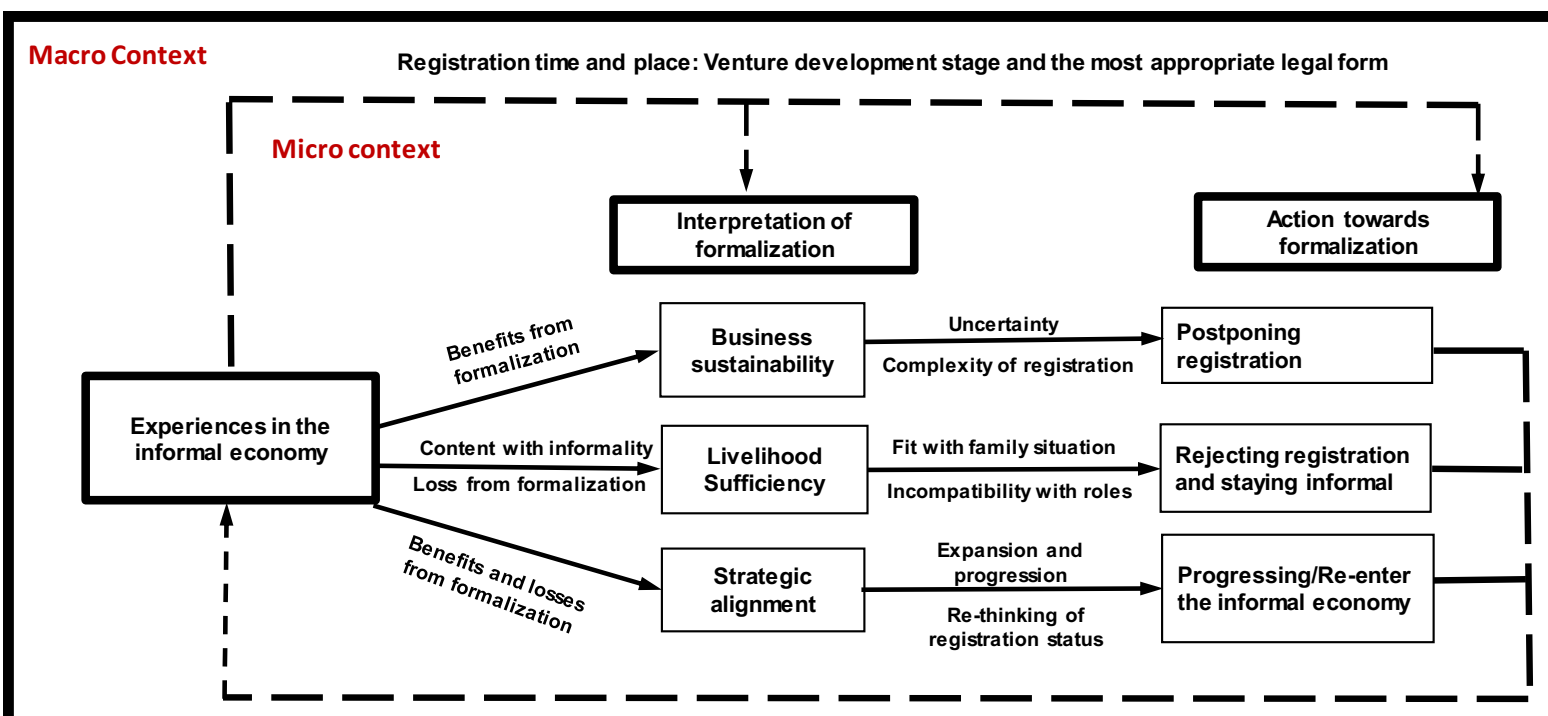

Formal-Informal status: Experience with registration and changes on life-course of women entrepreneurs

Fig. 1 Sensemaking process of business formalization based on the experiences in the informal economy, interpretation of formalization, and action towards formalization. Macro context including the formal

institutional environment (Uzo and Mair 2014) better captures the liminal character and lived-in experience of differing institutional effects.

Most literature suggests women's understanding of formalization reflects their aspirations for their businesses, their expectations or their livelihood needs (Williams and Gurtoo 2011; Babbitt et al. 2015). However, our data suggested a more complex picture of the social resources and constraints underpinning women entrepreneurs' account of the value of formalization, in the form of cultural, symbolic as well as social resources. Within wider institutional structures, for some women formalization was incompatible with family commitments and social expectations as it involved conducting business away from home and travelling unaccompanied at late hours for business activities or working long hours. For others, the constraints associated with the formalization process, dependencies on others for various forms of documentation and, more generally, a lack of confidence in women's business ventures made formalization unlikely.

Formalization is thus a double-edged sword. While it conveys normative aspirations associated with legitimate business, it also raises ethical implications for women's lived contexts, as it carries the risk of compromising social status and household roles, by involving women in activities that are perceived as 'unwomanly' (Fonchingong 2005) in the context of countries like Nepal. Managing societal expectations about gendered roles, business status and running enterprises within such boundaries mean that many women in our research had to make sense of powerful and informal institutional context provides cues to the micro context, i.e. sensemaking of, and their choices in the (in)formal economy

and conflicting social and cultural pressures, producing a kind of 'double bind'. Bateson (1972) explains a double bind scenario as one whereby pressures evoke conflicting demands on different levels which, to the person involved within a decision-making context, make it difficult to define the nature of the conflict itself or act according to what is prescribed as the 'right' thing to do. In such scenarios, the contradictory nature of the demands themselves are not-or cannot be-challenged. While formalization as a strategy or business status is depicted as the ideal, normative outcome of business development within economic development policy, in the context of countries like Nepal it is an approach that can place women into scenarios of socio-cultural strain as well as erode their confidence as potentially successful entrepreneurs.

For these women, ethical considerations of operating in the informal economy included the narratives of benefits, survival, fulfilment of household needs and making wider contributions to the community. Rather than accepting the universal understanding of the informal economy as bad, undesirable, illegal, and unvirtuous and informal entrepreneurs and workers as marginalized and a burden to the formal economy, we need to consider specific contexts where the value of 'right and wrong' could be evaluated (Bauman 2004, cited in Longondjo Etambakong and Roloff). Through this perspective, we see that for women entrepreneurs conforming to social roles is more virtuous than complying with formal regulations. The complexity of business formalization decisions thus needs to be more closely examined in 
relation to the social context of decision-making and the strong social institutions within-and without-which the informal economy operates (De Castro, et al. 2014).

Second, and following from the above, our paper adds to debates on the formalization literature about the inaccuracies of any implied divide between the formal-informal economy. De Castro et al. (2014) have shown that this dichotomous approach fails to capture the different dimensions of informality in developing country contexts. By illustrating the different levels of engagement of women with their environment, our data help to move this discussion further by demonstrating that those businesses that strategically operate liminally and delay registration-if only as a short term strategy — build stronger foundation for better performance than their registered counterparts (Williams et al. 2017). Our findings also showed that engaging in the informal economy provided some women entrepreneurs with a safety net for developing their experience and confidence to formalize. Similarly, they also utilized their informal status to build trust and relationships among suppliers, clients and their community.

While researchers have argued for enforcement and visits from compliance officers to force formalization (Andrade et al. 2014) our findings show that enforcing formalization may at best have only a temporary effect and could in the longer term even be counterproductive, for example by exposing women to social and cultural risks prematurely. The nuanced insight we gained from our participants was that of women at the centre of a series of carefully managed demands, commitments and expectations, whereby interventions concerning the manner of their access to the informal economy can have personal, social and cultural ramifications and, ultimately, be counterproductive. Working in the space between formal and informal and allowing women's emerging businesses to grow and formalize at times that align with their social, personal and cultural circumstances, seems to be a more supportive business strategy than enforced formalization.

Third, the focus on sensemaking allows us to highlight how social interactions act as localized feedback mechanisms for prompting certain lines of action with regards to formalization. This has implications for the broader literature on the contextual embeddedness of entrepreneurship (Welter 2011) and more specifically, the role of social capital in facilitating social interaction, building trust and supporting knowledge exchange (Grant 2013; Gianetti and Simonov 2004). Sensemaking also highlights an aspect of human capital often overlooked by an emphasis on the 'formal', because it stresses the practical, the intuitive and the social aspects of business choices and strategy, suggesting the need for alternative evaluative mechanisms of business development. We show how influences such as social norms, peer pressure (e.g. from family and friends who may approve or disapprove of registration) and social capital (Mickiewicz et al. 2019; Lindvert et al. 2017) explain to a large extent women's interpretation of formalization and their decisions thereof. All the participants revealed the importance of social circles/networks - weak or strong - in their decisions. Those women who adopted a livelihood sufficiency lens considered formalization as irrelevant which was reinforced by strong social circles. Weak social circles, on the other hand, provided crucial positive reinforcement towards registration, offered basic information and helped some participants to develop self-confidence on their ability to register. As other studies suggest individuals follow and abide by socially accepted beliefs in order to build and maintain social relationships (Cohen et al. 2012), suggesting that women conformed to their social groups in order to maintain their relationships, with implications for their registration decisions.

\section{Concluding Remarks and Implications}

This paper aimed to understand how women entrepreneurs in the informal economy make formalization decisions and with what ethical implications. While we acknowledge the wider role of the institutional framework in guiding individual behaviour and providing meaning to their actions, our use of a sensemaking approach offered a micro-level account of formalization amongst women in the developing country context of Nepal, which experiences high participation rates in the informal economy. Based on a qualitative investigation of women entrepreneurs, we identified three groups of women with varied understandings of formalization, which were enacted in making formalization decisions. Our findings highlight the salience of non-economic factors and constraints underpinning women entrepreneurs' actions, including cultural and social resources. We argue that the dominant view of formalization as ethical and virtuous and informality as unvirtuous needs to be better understood. We highlight the need for alternative conceptions of the ethics of formalization to pay closer attention to context if we are to understand the barriers to, and implications of, formalization behaviours. We believe that our findings add to existing literature on the formalization of the informal economy and women entrepreneurship by showing what facilitates and impedes formalization.

Additionally, our findings have implications for formalization policies especially given the recent interest in the South Asian region to target women entrepreneurs to register, by providing guidance and financial support with the registration process (ILO 2014). Previous studies have already shown that improving registration processes and information does not facilitate formalization (Andrade et al. 2014; De Mel et al. 2013). Instead, we show that while provision of information 
provides cues about a situation, the provider of the information (i.e. social circles) is more important. Formalization can be enacted through the use of role models of successful women entrepreneurs, who support other women and play an important role in changing formalization narratives. We support Williams and Nadin's (2014) suggestions for the need to move beyond blanket approaches to formalization that fail to account for the particularities of contexts and the groups that constitute them. Policies can only be improved by a nuanced understanding of how formalization choices unfold in particular environments considering the subtleties of socio-cultural contexts, the stage of business development and in particular recognize the importance of gender when nurturing ethical conceptions of formalization and tailoring business development support.

Finally, we took an interpretative approach to our research question and our analysis was based on qualitative data from a small number of interviews in a very specific context. We do not see this as a limitation of our research as we did not set out to make generalizations from our research but to seek more nuanced insight into the issues we describe. Our goal is that these insights into women's decisions helps develop more realistic models of business formalization that are relevant to women in the developing country context. Future research could however further explore the feasibility of formalization, its risks and impact on women's business, their households and their lives, given the policy imperative of formalizing the informal economy.

Acknowledgements Thanks goes to our Research Assistants who supported the data collection process in Nepal. Our heartfelt thanks go to all the women entrepreneurs who despite being busy gave us the opportunity to interview them. We are also grateful to the reviewers for providing us with constructive comments and feedback.

Funding This project was funded by the Centre for Economic Policy Research and the Department for International Development, UK within their Private Sector Development Scheme, Exploratory Research Grant No 2533.

\section{Compliance with Ethical Standards}

Conflict of Interest The authors declare that they have no conflict of interest.

Ethical Approval This study has been approved by the University of Sussex Research Ethics and Governance Committee (ethical approval number-ER/MX29/2) and have been performed in accordance with the ethical standards as laid down in the 1964 Declaration of Helsinki and its later amendments or comparable ethical standards.

Informed consent Informed consent was obtained from all individual participants included in the study.

Open Access This article is licensed under a Creative Commons Attribution 4.0 International License, which permits use, sharing, adaptation, distribution and reproduction in any medium or format, as long as you give appropriate credit to the original author(s) and the source, provide a link to the Creative Commons licence, and indicate if changes were made. The images or other third party material in this article are included in the article's Creative Commons licence, unless indicated otherwise in a credit line to the material. If material is not included in the article's Creative Commons licence and your intended use is not permitted by statutory regulation or exceeds the permitted use, you will need to obtain permission directly from the copyright holder. To view a copy of this licence, visit http://creativecommons.org/licenses/by/4.0/.

\section{Reference}

Adhikari, D. B. (2011). Income generation in informal sector: A case study of the street vendors of Kathmandu Metropolitan City. Economic Journal of Development Issues, 13 \& 14(1-2), 14.

Afram, G. G., \& Del Pero, A. S. (2012). Nepal's investment climate: Leveraging the private sector job creation and growth. Washington DC: The World Bank.

Ahl, H. (2006). Why research on women entrepreneurs needs new directions. Entrepreneurship Theory and Practice, 30, 595-621.

Andrade, G. H., Bruhn, M., \& Mckenzie, D. (2014). Helping hand or the long arm of the law? Experimental evidence on what governments can do to formalize firms. The World Bank Economic Review, 30(1), 24-54.

Arendt, H. (1958). The human condition. Chicago: Chicago University Press.

Babbitt, L. G., Brown, D., \& Mazaheri, N. (2015). Gender, entrepreneurship, and the formal-informal dilemma: Evidence from Indonesia. World Development, 72, 163-174.

Bateson, G. (1972). Steps to an ecology of nind: Collected essays in nnthropology, psychiatry, evolution, and epistemology. Chicago: University Of Chicago Press.

Bauman, Z. (2004). Wasted lives: modernity and its outcasts. Cambridge, MA: Harvard University Press.

Bennett, J. (2009). Informal firms in developing countries: Entrepreneurial stepping stone or consolation prize? Small Business Economics, 34(1), 53-63.

Bruhn, M., \& Mckenzie, D. (2014). Entry regulation and formalization of microenterprises in developing countries. The World Bank Research Observer, 29(2), 186-201.

Bruni, A., Gherardi, S., \& Poggio, B. (2004). Entrepreneur-mentality, gender and the study of women entrepreneurs. Journal of Organizational Change Management, 17(3), 256-268.

Brush, C. G., de Bruin, A., \& Welter, F. (2009). A gender-aware framework for women's entrepreneurship. International Journal of Gender and Entrepreneurship, 1(1), 8-24.

Bruton, G. D., Ireland, R. D., \& Ketchen, D. J. (2012). Towards a research agenda on the informal economy. Academy of Management Perspectives, 26(3), 1-11.

Bushell, B. (2008). Women entrepreneurs in Nepal: What prevents them from leading the sector? Gender \& Development, 16(3), $549-564$.

Butler, J. (2005). Giving an Account of Oneself. New York: Fordham University Press.

Cardon, M. S., Stevens, C. E., \& Ryland Potter, D. (2011). Misfortunes or mistakes?: Cultural sensemaking of entrepreneurial failure. Journal of Business Venturing, 26(1), 79-92.

CBS. (2008). Report on the Nepal Labour Force Survey: Statistical Report. Kathmandu: Central Bureau of Statistics National Planning Commission Secretariat, Government of Nepal.

CBS. (2019). Report on the Nepal Labour Force Survey 2017/18Third Labour Force Survey. Nepal: Government of Nepal, National Planning Commission, Central Bureau of Statistics in Collaboration with International Labour Organisation. 
Chant, S., \& Pedwell, C. (2008). Women, gender and the informal economy: An assessment of ILO research and suggested ways forward. Geneva, Switzerland: International Labour Organization.

Clark Muntean, S., \& Ozkazanc-Pan, B. (2015). A gender interative conceptualization of entrepreneurship. New England Journal of Entrepreneurship, 18(1), 27-40.

Cohen, J., Manzon, G. B., Jr., \& Zamora, V. L. (2012). Contextual and individual dimensions of taxpayer decision making. Journal of Busienss Ethics, 126, 631-647.

De Castro, J. O., Khavul, S., \& Bruton, G. D. (2014). Shades of grey: How do fnformal firms navigate between macro and meso institutional environments? Strategic Entrepreneurship Journal, 8(1), 75-94.

De Mel, S., Mckenzie, D., \& Woodruff, C. (2013). The demand for, and consequence of, formalisation among informal firms in Sri Lanka. American Economic Journal: Applied Economics, 5(2), $122-150$

De Soto, H. (1989). The other path: The economic answer to terror. Nework: Harper and Row Publishers.

De Vita, L., Mari, M., \& Poggesi, S. (2014). Women entrepreneurs in and from developing countries: Evidence from the literature. European Management Journal, 32(3), 451-460.

DeTienne, D. R., \& Chandler, G. N. (2007). The role of gender in opportunity identification. Entrepreneurship Theory and Practice, 31(3), 365-386.

Dix, S. (2011). Corruption and anti-corruption in Nepal: Lessons learned and possible future initiatives. Oslo: Norwegian Agency for Development Cooperation.

Fonchingong, C. C. (2005). Negotiating livelihoods beyond Beijing: The burden of women food vendors in the informal economy of Limbe, Cameroon. International Social Science Journal, 57(184), 243-253.

Geertz, C. (1993). The interpretation of cultures. London: Fontana.

Gianetti, M., \& Simonov, A. (2004). On the determinants of entrepreneurial activity: Social norms, economic environment and individual characteristics. Swedish Economic Policy Review, 11, 44.

Gioia, D., \& Thomas, J. (1996). Identity, image, and issue interpretation: Sensemaking during strategic change in academia. Administrative Science Quarterly, 41(3), 370-403.

Grant, R. (2013). Gendered Spaces of informal entrepreneurship in Soweto, South Africa. Urban Geography, 34(1), 86-108.

ILO. (2005). A report on micro and small enterprise policy review in Nepal 2003. Kathmandu: International Labour Office, International Labour Organisation.

ILO. (2014). Transitioning from the informal to the formal economy Report V(1). Paper presented at the International Labour Conference, 103rd Session, Geneva

ILO Nepal. (2014). Nepal labour market update. International Labour Organization, Country Office for Nepal.

Kabeer, N. (2012). Women's economic empowerment and inclusive growth: labour markets and enterprise development SIG Working Paper 2012/1. London: School of Oriental and African Studies.

Lindvert, M., Patel, P. C., \& Wincent, J. (2017). Struggling with social capital: Pakistani women micro entrepreneurs' challenges in acquiring resources. Entrepreneurship \& Regional Development, 29(7-8), 759-790.

London, T., Esper, H., Grogan-Kaylor, A., \& Kistruck, G. M. (2014). Connecting Poverty to Purchase in Informal Markets. Strategic Entrepreneurship Journal, 8(1), 37-55.

Longondjo Etambakonga, C., \& Roloff, J. (2020). Protecting environment or people? Pitfalls and merits of informal labor in the Congolese recycling industry. Journal of Business Ethics, 161(4), 815-834.

Maloney, W. F. (2004). Informality revisited. World Development, 32(7), 1159-1178.
Marlow, S., \& McAdam, M. (2013). Gender and entrepreneurship: Advancing debate and challenging myths; exploring the mystery of the under-performing female entrepreneur. International Journal of Entrepreneurial Behaviour and Research, 19(1), 114-124.

Mckenzie, D., \& Woodruff, C. (2007). Do entry costs provide an empirical basis for poverty traps? Evidence from Microenterprises. Economic Development and Cultural Change, 55(1), 3-42.

Meagher, K. (2013). Unlocking the informal economy: A literature review on linkages between formal and informal economies in developing countries. Women in Informal Employment Globalising and Organizing. Manchester, England: WIEGO.

Menon, N., \& Rodgers, Y. M. (2015). War and women's work: Evidence from the conflict in Nepal. Journal of Conflict Resolution, 59(1), 51-73.

Mickiewicz, T., Rebmann, A., \& Sauka, A. (2019). To pay or not to pay? Business owners' tax morale: Testing a neo-institutional framework in a transition environment. Journal of Business Ethics, 157, 75-93.

Mitra, A. (2005). Women in the urban informal sector: Perpetuation of meagre earnings. Development and Change, 36(2), 291-316.

Ness, A., \& Connelly, S. (2017). Situational influences on ethical sensemaking: Performance pressure, interpersonal conflict, and the recipient of consequences. Human Performance, 30(2-3), $57-78$.

Neves, D., \& Du Toit, A. (2012). Money and sociality in South Africa's informal economy. Africa, 82(1), 131-149.

North, D. C. (1990). Institutions, institutional change and economic performance (Political Economy of Institutions and Decisions). Cambridge: Cambridge University Press.

Perry, G. E., Maloney, W. F., Arias, O. S., Fajnzylber, P., Mason, A. D., \& Saavedra-Chanduvi, J. (2007). Informality: Exit and exclusion. Washington DC: The World Bank.

Pratt, M. (2000). The good, the bad, and the ambivalent: Managing identification among Amway distributors. Administrative Science Quarterly, 45, 456-493.

Ramani, S. V., Thutupalli, A., Medovarszki, T., Chattopadhyay, S., \& Ravichandran, V. (2013). Women entrepreneurs in the informal economy: Is formalisation the only solution for business sustainability? Working Paper Series, 18,

Rouse, J., Treanor, L., \& Fleck, E. (2013). The gendering of entrepreneurship: Theoretical and empirical insights. International Journal of Entrepreneurial Behaviour \& Research, 19(5), 452-459.

Scott, R. W. (2003). Institutional carriers: Reviewing modes of transporting ideas over time and space and considering their consequences. Industrial and Corproate Change, 12, 879-894.

Sharma, J., \& Donini, A. (2012). From subjects to citizens Labour mobility and social transformation in rural Nepal. Medford: Feinstein International Center, Tufts University.

Thomas, J. B., Clark, S. M., \& Gioia, D. A. (1993). Strategic sensemaking and organizational performance: Linkages among scanning, interpretation, action, and outcomes. Academy of Management Journal, 36, 239-270.

Trading Economics. (2016). Nepal Data. Retrieved October 25, 2019, from https://tradingeconomics.com/nepal/population.

UFPA (2017). Ending Child Marriage in Nepal.

Ulrichs, M. (2016). Informality, women and social protection: Identifying barriers to provide effective coverage. ODI Working Paper 435.

UNDP. (2015). Human development report 2015: Overview. Geneva: Work for Human Development United Nations Development Programme.

Uzo, U., \& Mair, J. (2014). Source and patterns of organizational defiance of formal institutions: Insights from Nollywood, the Nigerian Movie Industry. Strategic Entrepreneurship Journal, 8(1), 56-74. 
Vanek, J., Chen, M. A., Carre, F., Heintz, J., \& Hussmanns, R. (2014). Statistics on the informal economy: Definitions, regional estimates \& challenges. Second Edition, WIEGO Working Papers,

Viswanathan, M., Echambadi, R., Venugopal, S., \& Sridharan, S. (2014). Subsistence entrepreneurship, value creation, and community exchange systems: A social capital explanation. Journal of Macromarketing, 34(2), 213-226.

Webb, J. W., Tihanyi, L., Ireland, R. D., \& Sirmon, D. G. (2009). You say illegal, I say legitimate: Entrepreneurship in the informal economy. Academy of Management Review, 34(3), 492-510.

Weber, K., \& Glynn, M. A. (2006). Making sense with institutions: Content, thought and action in Karl Weick's theory. Organization Studies, 27(11), 1639-1660.

Weick, K. W. (1995). Sensemaking in organizations. Thousand Oaks, CA: Sage.

Weick, K. W., Sutcliffe, K. M., \& Obstfeld, D. (2005). Organizing and the process of sensemaking. Organization Science, 16(4), 409-421.

Welter, F. (2011). Contextualizing entrepreneurship: Conceptual challenges and ways forward. Entrepreneurship Theory and Practice, $35,165-184$.

Williams, C. (2009). Informal entrepreneurs and their motives: A gender perspective. International Journal of Gender and Entrepreneurship, 1(3), 219-225.

Williams, C., \& Nadin, S. J. (2010). Entrepreneurship and the informal economy: An overview. Journal of Developmental Entrepreneurship, 15(4), 361-378.

Williams, C., \& Nadin, S. J. (2014). Facilitating the formalisation of entrepreneurs in the informal economy. Journal of Entrepreneurship and Public Policy, 3(1), 33-48.
Williams, C., \& Shahid, M. S. (2016). Informal entrepreneurship and institutional theory: Explaining the varying degrees of (in)formalization of entrepreneurs in Pakistan. Entrepreneurship \& Regional Development, 28(1-2), 1-25.

Williams, C. C., \& Gurtoo, A. (2011). Women entrepreneurs in the indian informal sector: Marginalisation dynamics or institutional rational choice. International Journal of Gender and Entrepreneurship, 3(1), 1-28.

Williams, C. C., Martinez-Perez, A., \& Kedir, A. M. (2017). Informal entrepreneurship in developing economies: The impacts of starting up unregistered on firm performance. Entrepreneurship Theory and Practice, 41(5), 773-799.

World Bank. (2016). Doing business 2016: Measuring regulatory quality and efficiency: Economy profile. Kathmandu: WorkBank.

Xheneti, M., Thapa Karki, S., \& Madden, A. (2019a). Negotiating business and family demands within a patriarchal society: The case of women entrepreneurs in the Nepalese context. Entrepreneurship and Regional Development, 31(3-4), 259-278.

Xheneti, M., Madden, A., \& Thapa Karki, S. (2019b). The value of formalisation for women entrepreneurs in developing contexts: A review and research agenda. International Journal of Management Reviews, 21(1), 3-23.

Publisher's Note Springer Nature remains neutral with regard to jurisdictional claims in published maps and institutional affiliations. 